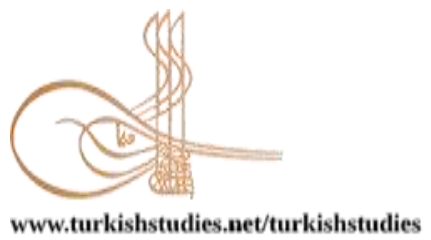

Turkish Studies

www.turkishstudies.net/turkishstudies

eISSN: $1308-2140$

BALKAN
UNIVERSITY

Sponsored by IBU

Research Article / Araștırma Makalesi

\title{
Covid-19 Pandemisi Dönemindeki Reklamların Kurumsal Sosyal Sorumluluk Açısından İncelenmesi
}

\author{
Investigation of Ads During the Covid-19 Pandemic from the Point of Corporate Social \\ Responsibility
}

\author{
Perihan Ş1ker*
}

\begin{abstract}
In today's competitive atmosphere, the number of businesses that make corporate social responsibility (CSR) an essential part of their activities increases with each passing day. CSR serves as a useful marketing tool in developing brand image by creating a competitive advantage for businesses. With the solutions they bring to social problems, businesses are noticeable among their competitors and become a more preferred brand by the consumer. Particularly unexpected situations that profoundly influence the society also affect the communication strategies of brands. In such periods, consumers' expectations from brands regarding voluntary responsibilities rise. The Covid-19 outbreak, which has hit the whole world, has also been one of the periodic crises worldwide. Social responsibility efforts to build an emotional bond with the consumer before Covid-19 have become much more critical with the epidemic process. In the process of the Covid-19 epidemic, brands play an active role in fighting the epidemic with the social messages they give in advertisements while supporting the fight against the epidemic by providing medical supplies or donating money directly. In this study, the most-watched ads on YouTube, which covered the fight against the epidemic in March when quarantine measures began to be taken in Turkey, were evaluated. In the study, a general evaluation of CSR reflections in advertisements has been done. These advertisements have been analyzed by applying the semiotic method. While the seven commercials considered within the study's scope generally emphasize the necessity for people to stay at home during the epidemic period, it was determined that visuals and sounds were employed for concepts such as unity and solidarity, struggle together, and gratitude. In all seven commercials that were analyzed, brands acted with the awareness of social responsibility. They gave messages reminding their target audience of the measures to be taken during the epidemic period rather than product promotion. The fact that these ads are among the most-watched ads on YouTube in March reveals consumers' expectations about CSR from brands have increased during such periods. Consequently, the brand images of businesses participating in such efforts are encouraged, and these businesses are regarded more positively by consumers and the public.
\end{abstract}

Structured Abstract: CSR, which is influential in developing emotional bonds among the customers and brands, is generally used by brands, primarily in natural crises. Billions of people worldwide are confronted with many adverse situations such as economic crisis, war, natural disaster, disease from time to time and the disasters encountered engraves society. The coronavirus epidemic, which first started in China in December 2019, has deeply affected many industries in the world. The epidemic started to spread rapidly worldwide and

\footnotetext{
* Dr. Öğr. Üyesi, Niğde Ömer Halisdemir Üniversitesi, İletişim Fakültesi, Halkla İlişkiler ve Reklamcılık Bölümü Asst. Prof. Dr., Nigde Omer Halisdemir University, Faculty of Communication, Department of Public Relations and Advertising$$
\text { ORCID 0000-0002-0787-8516 }
$$

gungorperihan@hotmail.com

Cite as/ Atıf: Şıker, P. (2020). Covid-19 pandemisi dönemindeki reklamların kurumsal sosyal sorumluluk açısından incelenmesi. Turkish Studies, 15(8), 3775-3791. https://dx.doi.org/10.7827/TurkishStudies.46411

Received/Geliş: 17 September/Eylül 2020

Accepted/Kabul: 20 December/Aralık 2020

Checked by plagiarism software

Copyright $($ C) MDE, Turkey

Published/Yayın: 25 December/Aralık 2020

CC BY-NC 4.0
} 
in February 2020, the disease was named Covid-19 by the World Health Organization (WHO). Due to the spread of the disease worldwide, it was declared a pandemic by WHO in March 2020. Undoubtedly, the pandemic period has started to change many conditions socially and economically all over the world. Brands have begun to review their communication strategies in this process. "According to the "Trust Barometer Special Report" research, consumers demand that brands act differently and communicate during the Covid19 crisis. About two-thirds (65\%) of those surveyed predict that how brands will respond to the pandemic will have an enormous impact on the possibility of purchasing their products in the future (Edelman, 2020). Shaikh (2020) argues that after the Covid-19 outbreak, there will be permanent differences in consumer behavior and some aspects of marketing responses. Brands aware of this situation and ready for this situation will emerge more strongly from the epidemic.

The Covid-19 pandemic grants excellent opportunities for brands to engage with CSR strategies actively. In these challenging times, brands giving messages that show their concern about the consumer are likely to come to the fore. If the brands tell the consumers how much they care about public health with the right movements, it will influence their brand preference. The voluntary participation of brands in CSR programs is due to the fact that brands' marketing efforts including CSR is perceived more positively by the consumers. Significantly, consumers' expectations concerning CSR from brands increase even more in times of natural crisis. During this period, most brands began to give messages containing more CSR by changing the messages' content in their advertisements. This study aimed to draw a general picture of CSR's reflections in the advertisements published during the pandemic period. These advertisements were analyzed by the semiotic method. Semiotics, which is applied in analyzing the message in advertising communication, examines the linguistic and visual elements of the message (Küçükerdoğan, 2005). With the content conveyed to the target audience in advertisements, the target audience's behavior and attitudes are directed. In this context, semiotics guides the analysis of linguistic and visual elements introduced to the advertisements' target audience. In this study, the most-watched advertisements about the epidemic on YouTube in March, when epidemic measures began to be taken in Turkey, were analyzed with the trilogy of indication, indicator and indicated by Barthes, one of the crucial linguists of semiotics. The most-watched advertisements on YouTube in March were reached from the "YouTube Ads Leaderboard" which is regularly declared by Google every month. When the ads in the list of the ten most-watched commercials on YouTube were examined, the subject of the commercial films' of Arçelik, Turkcell, Türkiye İş Bank, Vakıfbank, Beko, Yemek Sepeti, and QNB Finansbank was the Covid-19 outbreak. These advertisements form a sample of the research. The study's limitation is that there is no sectoral distinction in the advertisements considered in the study. The advertisements are limited to March when the Covid-19 epidemic started in Turkey.

As a result of the analysis, it is observed that the brands deliver optimistic messages to their customers, such as being for them in these uncertain times. It has been determined that texts, visuals, and sounds for concepts like unity and solidarity, struggling together, and gratitude are applied in the analyzed advertisements. The common point of all seven commercials is that this crisis will be overcome with unity and solidarity. The analyzed commercial of the Arçelik brand focuses on people over the age of 65 . It includes verbal and visual codes that hold the value and cooperation which Turkish society provides to its elders. In Turkcell and Türkiye İş Bank advertisements, individuals are shown inside the house, and the call to stay at home is repeated. In these advertisements, where Turkish society's values regarding the family institution are tried to be conveyed through verbal and visual codes, it is demonstrated that the difficult days will be defeated with the feeling of unity and solidarity, and the good old days will come again. Likewise, in Vakıfbank's advertisement, that all difficulties will be overcome with social solidarity is emphasized. It is also highlighted with visual and verbal codes that Vakifbank stands by every segment of the society. On the other hand, Yemek Sepeti advertisement draws attention to the fact that Turkish society, which is in solidarity under challenging times, can provide support by ordering food from restaurants in a difficult situation during the pandemic period. Beko and QNB Finansbank brands, highlighting healthcare professionals, covered more indicator codes such as gratitude and solidarity in their advertisements. When the ads are evaluated in general, brands give a standard message that they are concerned about their customers' health and focus on people staying at home. In all seven commercials, the phenomenon of "we" instead of "me" was featured, and linguistic and visual signs indicating social unity and solidarity were prominently featured.

As a result, consumers will remember how brands reacted when they looked back at the Covid-19 period. Therefore, brands must manage this process properly and make accepted CSR efforts in this period when consumers become more sensitive. It indicates that people spend more time at home during the pandemic, 
watch more television, and spend more time on social media. Thus, the advertisements produced during this period reach vast audiences in a short time. Social messages given in advertisements produced especially during this period, within the scope of fighting the epidemic instead of calling the consumer to buy the product will contribute to the brands gaining a more powerful place in consumers' hearts.

Keywords: Corporate Social Responsibility, Advertising, Covid-19, Pandemic, Semiotics.

Öz: Günümüzün rekabetçi ortamında kurumsal sosyal sorumluluğu (KSS) faaliyetlerinin önemli bir parçası haline getiren işletme sayısı gün geçtikçe artmaktadır. KSS, işletmelere rekabet avantajı yaratarak marka imajı geliştirmede etkili bir pazarlama aracı olarak hizmet etmektedir. İşletmeler, toplumsal sorunlara getirdikleri çözümler ile rakipleri arasında fark edilebilir hale gelmekte ve tüketici tarafindan daha çok tercih edilebilmektedir. Özellikle toplumu derinden etkileyen beklenmedik durumlar markaların iletişim stratejilerini de etkilemektedir. Tüketicilerin böyle dönemlerde markalardan gönüllü sorumlulukla ilgili beklentileri artmaktadır. Tüm dünyayı etkisi altına alan Covid-19 salgını dünya tarihinde nadir görülebilecek krizlerden biri olmuştur. Covid-19 öncesi tüketici ile duygusal bağ oluşturmak için yapılan sosyal sorumluluk çalışmaları, salgın süreci ile birlikte çok daha önemli hale gelmiş̧ir. Covid-19 salgını sürecinde, markalar bir taraftan tıbbi malzemeler üreterek ya da doğrudan para bağışlayarak salgınla mücadeleye destek verirken bir taraftan da reklamlarda verdikleri sosyal mesajlarla salgınla mücadelede aktif rol oynamaktadırlar. Bu çalışmada, Türkiye'de karantina önlemlerinin alınmaya başlandığı 2020 Mart ayında salgınla mücadeleyi konu edinen ve YouTube'da söz konusu dönemde en çok izlenen reklamlar değerlendirilmeye alınmıştır. Çalışmada, KSS'nin reklamlardaki yansımalarının genel bir değerlendirmesi yapılmış olup söz konusu reklamlar göstergebilimsel yöntemden hareketle çözümlenmiştir. Çalışma kapsamında ele alınan yedi reklam filmi genel olarak insanların salgın döneminde evde kalmalarının gerektiğini vurgularken, reklamlarda birlik ve beraberlik, birlikte mücadele, dayanışma, minnettarlık gibi kavramlara yönelik görsel ve dilsel ifadeler kullanıldı̆̆ edilmiş̧ir. İncelenen yedi reklam filminde de markalar, sosyal sorumluluk bilinciyle hareket ederek ürün tanıtımından ziyade hedef kitlelerine salgın döneminde alınması gereken önlemleri hatıllatan mesajlar vermişlerdir. Söz konusu reklamların Mart ayında YouTube'da en çok izlenen reklamların içerisinde olması da tüketicilerin markalardan böyle dönemlerde KSS ile ilgili beklentilerinin arttığını göstermektedir. Sonuç olarak, bu tür çabalar içerisinde yer alan işletmelerin marka imajları güçlenmekte ve bu işletmeler, tüketiciler ve kamuoyu tarafindan daha olumlu algilanmaktadır.

Anahtar Kelimeler: Kurumsal Sosyal Sorumluluk, Reklam, Covid-19, Pandemi, Göstergebilim.

\section{Giriş}

Günümüzde bir markayı tüketicinin zihninde ilk sıralarda tutabilmek gittikçe zorlaşmaktadır. Artık her marka tüketiciye özel çözümler sunmakta, uzun dönem garantiler vermekte, ürün çeşitliliği gibi birçok kolaylık sağlamaktadır. Birbirine benzer seçeneklerin tüketiciye sunulması nedeniyle artık tüketiciler markaları sadece rasyonel açıdan birbirleriyle karşılaştırmamakta, marka seçimlerini daha çok duygularla yapmaktadırlar. Tüketicilerin marka ile duygusal bağ geliştirmesinde etkili olan KSS, özellikle doğal krizlerin yaşandığı dönemlerde markalar tarafından sıklıkla kullanılmaktadır. Dünyada milyonlarca insan dönem dönem ekonomik kriz, savaş, doğal afet, hastalık gibi birçok olumsuz durumla karşı karşıya kalmakta ve yaşanan felaketler toplumda derin izler bırakmaktadır. İlk kez Aralık 2019'da Çin'de başlayan koronavirüs salgını da insanları derinden etkilemiştir. Salgın hızla tüm dünyada yayılmaya başlamış ve 2020 Şubat ayında Dünya Sağlık Örgütü (WHO) tarafından hastalığa Covid-19 adı verilmiştir. Hastalığın dünya çapında yayılması nedeniyle WHO tarafından 2020 Mart ayında pandemi ilan edilmiştir. Şüphesiz ki pandemi dönemi, tüm dünyada sosyal ve ekonomik anlamda birçok şeyi değiştirmeye başlamıştır. Markalar da bu süreçte iletişim stratejilerini yeniden gözden geçirmeye başlamışlardır. "Trust Barometer Special Report" araştırmasına göre, tüketiciler, Covid-19 krizi sırasında markaların farklı hareket etmesini ve iletişim kurmasını talep etmektedir. Araştırmaya katılanların yaklaşık üçte ikisi (\% 65) markaların pandemiye nasıl tepki vereceğinin, gelecekte ürünlerini satın alma olasılıkları üzerinde büyük bir etkiye sahip olacağını öngörmektedir (Edelman, 2020). Shaikh (2020), Covid-19 salgını sonrası, 
tüketici davranışlarında ve tüketicilerin bazı pazarlama tepkilerinde kalıcı değişiklikler olacağını ve bu durumun farkında olan ve bu duruma hazırlıklı olan markaların salgından çok daha güçlü bir şekilde çıkacağını ileri sürmektedir.

Kriz zamanlarında yaşanan coğrafya, yaşam tarzı kültürel farklılık gösterse de toplumların dayanışma içinde ortak değerleri savundukları görülmektedir. Covid-19 salgınında, markaların hem üretim hem de iletişim boyutunda toplumun beklentilerini karşılayacak, toplumu birleştirici çalışmalarda bulunması gerekliliği kaçınılmazdır. Covid-19 salgını, şirketlere KSS stratejileri ile aktif bir şekilde ilgilenmeleri için büyük firsatlar sunmaktadır (He \& Harris, 2020). Birçok şirket bu dönemde, maske, el dezenfektanı, solunum cihazı gibi tıbbi malzeme üretimi sağlayarak ya da doğrudan para bağışında bulunarak dikkate değer KSS çalışmalarında bulunmuştur. Yine birçok marka bunlara ek olarak çalışanlarına yönelik evden çalışmaya imkan tanımış, bazı durumlarda çalışanlarına finansal destek sağlamıştır. Twitter'ın kurucusu ve patronu Jack Dorsey, Covid-19 salgınıyla mücadele etmek için 1 milyar dolar bağışta bulunmaya söz vermiştir (BBC, 2020a). Louis Vuitton sahibi LVMH, parfüm üretim hatlarını, Covid-19 salgınına karşı el dezenfektanı yapmaya başlamak için kullanacağını açıklamıştır (BBC, 2020b). Alibaba'nın kurucu ortağı Jack Ma, dünyadaki birçok ülkeye (BBC, 2020c) test kitleri ve diğer tıbbi malzemeler bağışlamıştır. Türkiye'de de markalar benzer şekilde salgınla mücadeleye yönelik bağışlarda bulunmuşlardır. Türkiye İş Bankası, hastanelere Covid-19 salgını ile mücadelede kullanılmak üzere 10 milyon TL bağışlama kararı almıştır. Arçelik markası, yerli solunum cihazı üreterek ve hastanelere çamaşır ve kurutma makinesi, fırın, çay, kahve ve tost makinesi bağışlayarak destek vermiştir. LC Waikiki markası ise maske üretip bağışlayan markalardan biri olmuştur. Görüldüğü üzere Covid-19 salgını, markalara KSS stratejileri ile aktif olarak ilgilenmeleri için büyük firsatlar sunmaktadır. Bu zor günlerde tüketiciyi önemsediğini gösteren mesajlar veren markaların ön plana çıkması muhtemeledir.

Markaların toplum sağlığını ne kadar önemsediğini doğru hamlelerle tüketiciye göstermesi tüketicinin marka tercihini etkileyecektir. Markaların KSS programlarına gönüllü olarak katılmalarının temelinde, markaların KSS içeren pazarlama çabalarının tüketici nezdinde daha olumlu algılanması yatmaktadır. Özellikle, tüketicilerin doğal kriz dönemlerinde markalardan KSS ile ilgili beklentileri daha da artmaktadır. Böyle dönemlerde, birçok marka reklamlarda verdikleri mesajların içeriklerini değiştirerek daha çok KSS içeren mesajlar vermektedir. Covid-19 salgını da birçok markanın reklam içeriklerini yeniden düzenlemesine neden olmuştur. Bu çalışmada, öncelikle KSS kavramı üzerinde durulmuş ve daha sonra markaların Covid-19 salgını döneminde yayınladıkları reklamlardaki görsel ve dilsel ögeler göstergebilimsel yöntemle analiz edilerek KSS açısından değerlendirilmiştir. Böylece markaların Covid-19 salgını sürecinde, reklam stratejilerinde nasıl bir yol izledikleri, kullandıkları ortak göstergeler karşılaştırmalı olarak ortaya koyulmuştur.

\section{Kurumsal Sosyal Sorumluluk}

KSS'nin geniş bir kapsam alanının olması net bir şekilde tanımlanmasını zorlaştırmaktadır. KSS kavramı 1953 yılında Howard Bowen'ın "İşadamının Sosyal Sorumlulukları" adlı kitabına kadar uzanmaktadır. Bowen'e (1953) göre KSS, "toplumun hedefleri ve değerleri ile uyumlu olan faaliyetleri takip etmek ve kararları almak için gerekli politikaları izleme zorunluluğu"dur. Avrupa Birliği Komisyonu (2001) KSS'yi, "işletmelerin, sosyal ve çevresel sorunları kendi iş süreçleri ve paydaşları ile olan ilişkilerine gönüllü olarak entegre etmesini öngören bir kavram" olarak tanımlamıştır. Komisyon KSS'nin tanımını 2011 yılında yeniden yaparak, "işletmelerin toplum üzerindeki etkilerinden dolayı sorumlulukları" olarak daha sade hale getirmiş̧ir. Aktan ve Börü (2006) KSS'yi, "herhangi bir organizasyonun hem iç, hem de diş çevresindeki tüm paydaşlara karş1 "etik" ve "sorumlu" davranması, bu yönde kararlar alması ve uygulaması" şeklinde tanımlamaktadır. Kotler ve Lee (2006) ise KSS'yi, "isteğe bağlı iş uygulamaları ve kurumsal kaynakların katkıları yoluyla toplumun refahını iyileştirmek için üstlenilen bir yükümlülük" olarak tanımlamışlardır. 
KSS, kurumların toplumsal refah için çeşitli değerlerini sıraya dizmeleri ve pozitif etkileri olan davranışlarda bulunmaları anlamına gelmektedir (Clow \& Baack, 2016). Ogrizek (2002), KSS'nin kapsamını sadece hayırseverlik ve toplum katılımı faaliyetleri olarak değil, aynı zamanda çevre yönetim sistemi, insan kaynakları politikası ve sürdürülebilir gelecek için stratejik yatırım gibi uygulamaları da kapsayacak şekilde tanımlamaktadır. İşletmeler, kurumsal imajlarını iyileştirmek ve pazarlama taktik etkilerini güçlendirmek ve böylece firma performansını olumlu yönde etkilemek için KSS yükümlülüklerini yerine getirmektedirler (Maignan, Ferrell \& Ferrell, 2005).

İşletmeler genellikle sahiplerine karşı sorumluluklarını düşünürler. Fakat KSS'nin önceliği, şirketlerin sadece sahipleri ve hissedarları için kar elde etmenin ötesinde ahlaki sorumluluklara sahip olmasıdır (Berman vd., 1999). Artık tüketiciler, markalardan sadece kaliteli ve düşük fiyatlı ürün beklemiyorlar aynı zamanda markaların sosyal ve etik faaliyetlerde bulunmalarını da bekliyorlar (Alcaniz, Cacarez \& Perez, 2010). KSS, işletmeler açısından ekonomik faaliyetlerin ötesinde gönüllü olarak daha iyi bir toplum ve daha temiz bir çevreye katkı sağlamanın altını çizmektedir (Carroll, 1999). Carroll'a göre KSS ekonomik, yasal, ahlaki ve gönüllü sorumluluk olmak üzere dört katmanlı bir piramitten oluşmaktadır (Carroll, 1991).

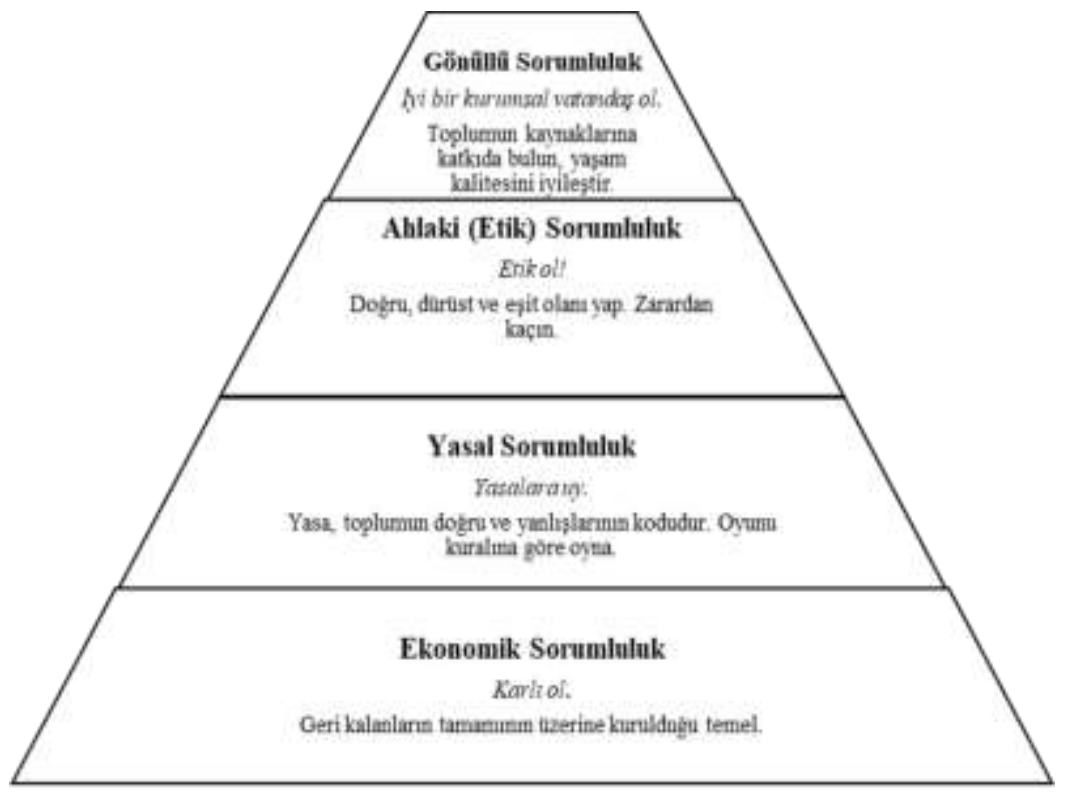

Şekil 1: Kurumsal Sosyal Sorumluluk Piramidi (Carroll,1991)

İlk katmanı oluşturan işletmenin ekonomik sorumluluğudur çünkü onsuz işletme topluma katkıda bulunan bir varlık olarak ayakta kalamaz. İşletmenin ekonomik sorumluluğu, toplumun istediği mal ve hizmetleri üretmek ve bunları karlı bir şekilde satmaktır. Yasal sorumluluk ise işletmelerin kar elde etme amacından sonra ikinci koşul olarak devletin ve yasaların beklentilerine uygun hareket etmesidir. Piramidin üçüncü basamağında yer alan ahlaki sorumluluk, işletmelerin faaliyetlerini toplumsal zorunluluk ve etik normlara uygun gerçekleştirmesidir. Son basamak olan gönüllü sorumluluk ise işletmenin kendi iradesi ile üstlendiği sorumlulukları ifade eder. Gönüllü sorumluluk işletmenin, kişilerin refahını artıracak programlara ya da eylemlere aktif olarak katılmasını içerir (Carroll, 1991). Özellikle toplumsal sorunların yaşandığı dönemlerde markaların tüketicilerle duygusal bağ oluşturmasında gönüllü sorumluluk faaliyetleri daha önemli hale gelmektedir. Böyle dönemlerde tüketiciyle empati ile iletişim kurmak ve krizin neden olduğu sorunları çözmeye odaklanmak, kriz sırasında da marka bağl1lığını sürdürülmesini sağlayacaktır (He \& Harris, 2020). 
Çalışmalar KSS faaliyetlerine katılmanın pazar payı, satış değeri, marka değeri üzerine olumlu etkiye sahip olarak pazarlama performansını artırdığını göstermektedir (Maignan, 2001; Chacal \& Sharma 2006; Lai vd. 2010, Ogrizek 2002). Araştırmacılar, KSS faaliyetlerine katılmanın aynı zamanda şirket için dürüst ve güvenilir bir itibar yarattığını ve müşterilerin bu tür şirketlerin ürün ve hizmetlerini daha güvenilir ve daha kaliteli olarak değerlendirdiğini öne sürmektedir (McWilliams \& Siegel, 2001). KSS, şirketlere yeni pazarlara girme ve müşteri sadakati sağlamada kolaylıklar sağlamakta, verimlilik ve kalite artışları yaşanmakta, risk yönetimi daha etkin hale gelmektedir (Argüden, 2002). İş dünyasındaki uzmanlar, sosyal sorumluluk sahibi firmaların, uzun dönemde daha çok ilerleme kaydedecekleri ve ayakta kalacakları konusunda hemfikirdir (Clow \& Baack, 2016).

\section{Reklamlarda Kurumsal Sosyal Sorumluluk}

Firmaların algılanan itibarlarını etkilemek için kullandıkları temel araçlardan ikisi KSS ve reklamdır (Smith \& An, 2019). Türk Dil Kurumu tarafından "bir şeyi halka tanıtmak, beğendirmek ve böylelikle sürümünü sağlamak için denenen her türlü yol" biçiminde tanımlanan reklam, geniş kitlelere ulaşmak için oldukça etkili bir iletişim aracıdır. Kotler ve Armstrong (2018) reklamı, "fikirlerin, ürünlerin ya da hizmetlerin belirli bir sponsor (şirket) tarafından belli bir ödeme yaparak sunulması ve tanitılması" olarak tanımlamaktadır. Amerikan Pazarlama Birliği'nin (American Marketing Association-AMA) yapmış olduğu reklam tanımı ise biraz daha geniş kapsamlıdır. AMA'nın tanımına göre, "Reklamcılık, belirli bir hedef pazarı oluşturan bireyleri ya da izleyicileri ürünlere, hizmetlere, organizasyonlara veya düşüncelere dair bilgilendirmek ve/veya ikna etmek amacıyla firmaların, kar amacı gütmeyen organizasyonların, kamu kurumlarının ve bireylerin ikna edici mesajlarını ve duyurularını, kitle iletişim araçlarına, yer veya zaman satın alarak yerleştirmesidir." (Elden, 2015). Tanımlardan da anlaşılacağı üzere reklamın temel amacı, işletmenin sunmuş olduğu mal ve hizmetlere karşı tüketicide olumlu bir tepki uyandırmaktır.

Reklam aynı zamanda, olumlu bir kurum imajı yaratmak ya da var olan imajı güçlendirmek, bir kişi, fikir ya da konu etrafinda olumlu bir kamuoyu yaratmak için de yapılabilir (Elden vd.,2005). Tüketicinin bir konuya ilgisini teşvik etmek için sosyal veya çevresel bilgiyi yaymaya odaklanmak, KSS kapsaminda kullanılan mesaj stratejilerinden birisidir (Kotler \& Lee, 2006) ve son yıllarda işletmeler tarafindan reklamlarda sıklıkla kullanılmaktadır. National Geographic'te 1979'dan 2008'e kadar yayınlanan reklamları inceleyen Bortree vd. (2013) reklamların ticari konulardan, işletmelerin, toplumun ve çevrenin sürdürülebilir gelişimine doğru kademeli olarak değiştiğini ifade etmektedir. Reklamların içeriklerindeki bu değişimler, KSS'nin günümüz tüketici pazarında önemli bir reklam stratejisi haline geldiğini göstermektedir. Reklam, büyük kitlelere ulaşarak, duygusal ve davranışsal tepkileri harekete geçirme kapasitesi olan güçlü bir araçtır (Salmones \& Perez, 2017). Özellikle sosyal içerikli reklamlar bir taraftan tüketicilerin toplumsal konulara ve sorunlara yönelik tepki geliştirmelerini sağlarken bir taraftan da markaya yönelik olumlu tutum geliştirmelerinde etkili olabilmektedir. Dolayısıyla, işletme tarafından para kazanmaktan başka bir tür girişimin gerçekleştirildiğini gösteren pazarlama faaliyetleri değer yaratmakta ve marka bilincinin teşvik edilmesine yardımcı olmaktadır (Baker ve Sinkula, 2005).

KSS reklamcılığı, bir şirketin ahlaki bir amaca (sosyal sorumluluk, çevresel koşullar, toplumsal duyarlı1ık vb.) yaptığı katkıyı belirtmek için kitle iletişim reklamlarında doğrudan veya dolaylı olarak metin, simge veya görüntülerin kullanılması anlamına gelmektedir (Yang, 2018). Şirketin belirli bir ürün tanıtmadan, çevresel ve toplumsal kaygıları ele aldığ 1 KSS reklamları, şirketlerin toplum tarafından nasıl algılanmak istendiğini gösterdiği için önemli bir çalışma alanıdır. Şirketler, KSS iletişimi için çoğunlukla sosyal raporlar, reklamlar, web siteleri gibi araçları kullanırlar. Ancak, KSS reklamcılığı, şirketlerin KSS iletişimi için kullandığı sosyal raporlar ve web siteleri ile karşılaştırıldığında en az araştırılan KSS iletişim aracıdır ve KSS reklamcılığı terimi yaygın olarak kullanılmamaktadır (Farache \& Perks, 2010). Bununla birlikte, toplumsal sorunları ele 
alan sosyal mesajların yer aldığı KSS reklamları son zamanlarda karşımıza sıklıkla çıkmaktadır. Özellikle tüm toplumu derinden etkileyen savaşlar, doğal afetler, ekonomik krizler, salgın hastalıklar gibi olumsuz olaylarda, markalar reklamlarında toplumsal duyarlılıkların ortaya koymaktadırlar. Bu nedenle, bu çalışmanın konusu da işletmelerin en kritik KSS iletişim araçlarından birisi olan KSS reklamcılığını kapsamaktadır. Bu bağlamda, reklamlarında Covid-19 salgını ile mücadeleyi konu edinen markaların, KSS açısından nasıl bir tutum sergilediklerinin araştırılması bu çalışmanın ana temasını oluşturmaktadır.

\section{Yöntem}

Tüm dünyayı etkisi altına alan Covid-19 salgını ile birlikte bazı markalar değiştirilmiş içerikle reklam vermeye devam ederken, bazı markalar duruma cevap vermemeyi tercih etmiştir. Bu süreçte reklam vermeye devam eden çoğu markanın salgınla mücadeleyi konu edindiği görülmüştür. $\mathrm{Bu}$ çalışma ile pandemi döneminde salgınla mücadeleyi konu edinen reklamlardaki KSS yansımalarının genel bir tablosunun çizilmesi hedeflenmiştir. $\mathrm{Bu}$ amaçla, KSS açısından reklamlardaki ortak temaların neler olduğu, nitel araştırma yöntemleri içerisinde yer alan göstergebilimsel yöntemden hareketle çözümlenerek incelenmiştir.

Reklam üzerine yapılan çalışmalar içerisinde üzerinde en çok durulan konulardan birisi de reklamların nasıl analiz edileceği, daha doğrusu reklamların görünenin altında hedef kitlesine ne gibi mesajlar aktardığının nasıl araştırılacağıdır (Elden vd., 2005). Reklamların analiz edilmesinde kullanılan yöntemlerden birisi, temelleri Amerikalı Charles Sanders Pierce ve İsviçreli Ferdinand de Saussure tarafından atılmış olan göstergebilimdir. Göstergeleri inceleyen bilim dalı olarak kabul gören göstergebilimin temelini, Saussure'un çalışmalarında göstergeyi, gösteren ve gösterilen olarak tanımlaması oluşturmaktadır. Saussure, gösteren ve gösterilenden oluşan göstergenin asıl olarak gösteren tarafiyla ilgilenmiştir. Saussure'ün gösterge anlayışına göre gösterge, gösteren olarak ağızdan çıkan sözcük ile gösterilen olarak zihindeki kavram arasındaki bağıntının ürünü olarak gerçekleşir ve dış dünya gerçeğini dışarıda bırakır (Sayın, 2014). Peirce'ın göstergesi ise gösteren ve gösterilenin yanı sıra yorumun devreye girmesiyle üç düzlemli hale dönüşmüştür. Saussure'den farklı olarak Peirce'e göre göstergeyi algılayan kişi, kendi zihninde eşdeğerini araştırır ve bir yorum yaparak kendi yorum göstergesini oluşturur (Erkman Akerson, 2005). Saussure'ün takipçilerinden Roland Barthes'a göre (2016), gösterge, bir gösteren ile bir gösterilenden kurulmakta ve gösterenler düzlemi anlatım düzlemini, gösterilenler düzlemi ise içerik düzlemini oluşturmaktadır. Göstergenin ortaya çıkmasını, gösterilen ile gösteren arasında kurulan bağıntı sağlamaktadır. Barthes'ın göstergebilim kuramında anlamlandırmanın düz anlam ve yan anlam olmak üzere iki düzeyi bulunmaktadır. Duyulan bir sözcüğün zihninde canlandırdığı ilk kavram, göstergenin düz anlamıdır. Duyulan bir sözcüğün çağrışım yoluyla oluşturulan farklı anlamlarını yüklenmiş kavramlar ise göstergenin yan anlamıdır (Sayın, 2014). Düz anlam nesnellik, bilişsellik ve mantıklılık gibi özellikler taşırken, yan anlam öznellik, duygusallık ve çağrışımsallık nitelikleri taşımaktadır (Küçükerdoğan, 2009). Reklam iletişiminde iletinin çözümlenmesi aşamasında başvurulan göstergebilim, iletinin dilsel ve görsel ögelerinin çözümlenmesini yerine getirir (Küçükerdoğan, 2005). Reklamlarda hedef kitleye aktarılan içerikle, hedef kitlenin davranış ve tutumları yönlendirilmeye çalış1lır. Bu bağlamda göstergebilim, reklamlarda hedef kitleye sunulan dilsel ve görsel ögelerinin çözümlenmesine rehberlik etmektedir.

$\mathrm{Bu}$ çalışmada, nitel bir araştırma yöntemi olan göstergebilimsel analiz yöntemi kullanılmıştır. Nitel araştırma, "gözlem, görüşme ve doküman analizi gibi nitel veri toplama yöntemlerinin kullanıldığı, algıların ve olayların doğal ortamda gerçekçi ve bütüncül bir biçimde ortaya konmasına yönelik nitel bir sürecin izlendiği araştırma" olarak tanımlanmaktadır (Yıldırım \& Şimşek, 2008). Tanımdan da anlaşılacağı üzere nitel araştırmalarda amaç, bütüncül ve gerçekçi bir resim ortaya koyarak olayları yorumlamaya çalışmaktır. Olasılık temelli olmayan örnekleme yöntemlerinden amaçlı örnekleme, nitel araştırmalarda sıklıkla kullanılan bir örnekleme yöntemidir. 
Amaçlı örneklemede, araştırmacının amacına en uygun olduğunu düşündüğü durumlar örneklem olarak seçilmektedir (Tanrıöğen, 2009). Amaçlı örnekleme yönteminin kullanıldığı bu çalışmada, araştırma örneklemi belirlenirken Türkiye'de Covid-19 salgını ile ilgili önlemlerin alınmaya başladığı 2020 Mart ayı içerisinde, YouTube'da en çok izlenen ve salgını konu edinen reklamlar ele alınmıştır. En çok izlenen reklamların listesine, Google'ın her ay düzenli olarak açıkladığ 1 "YouTube Ads Leaderboard" dan ulaşılmıştır. 2020 Mart ayında YouTube' da en çok izlenen on reklam filminin yer aldığı listedeki reklamlar incelendiğinde, Arçelik, Turkcell, Türkiye İş Bankası, Vakıfbank, Beko, Yemek Sepeti ve QNB Finasbank'a ait reklam filmlerinin Covid-19 salgınını konu edindiği görülmüştür. Söz konusu reklamlar araştırmanın örneklemini oluşturmaktadır. Çalışmada incelenen reklamlarda sektörel ayrım yapılmaması ve reklamların Türkiye'de Covid-19 salgınını başladığı Mart ayı ile sınırlandırılması çalışmanın kısıtını oluşturmaktadır.

\section{Reklamların Göstergebilimsel Analizi}

Reklamlar, göstergebilimin önemli dilbilimcilerinden biri olan Barthes'ın gösterge, gösteren ve gösterilenden oluşan üçlemesiyle incelenmiştir.

\section{Arçelik Reklamı}

İlk analiz yapılacak reklam filmi beyaz eşya markası Arçelik'e aittir. Reklam, Covid-19 salgını ile mücadele kapsamında Türkiye'de 65 yaş ve üzerine sokağa çıkma kısıtlaması getirildiği bir dönemde yapılmıştır. Bu nedenle reklamın ana temasını "önce büyükler" ifadesi ile yaşlılar oluşturmaktadır.
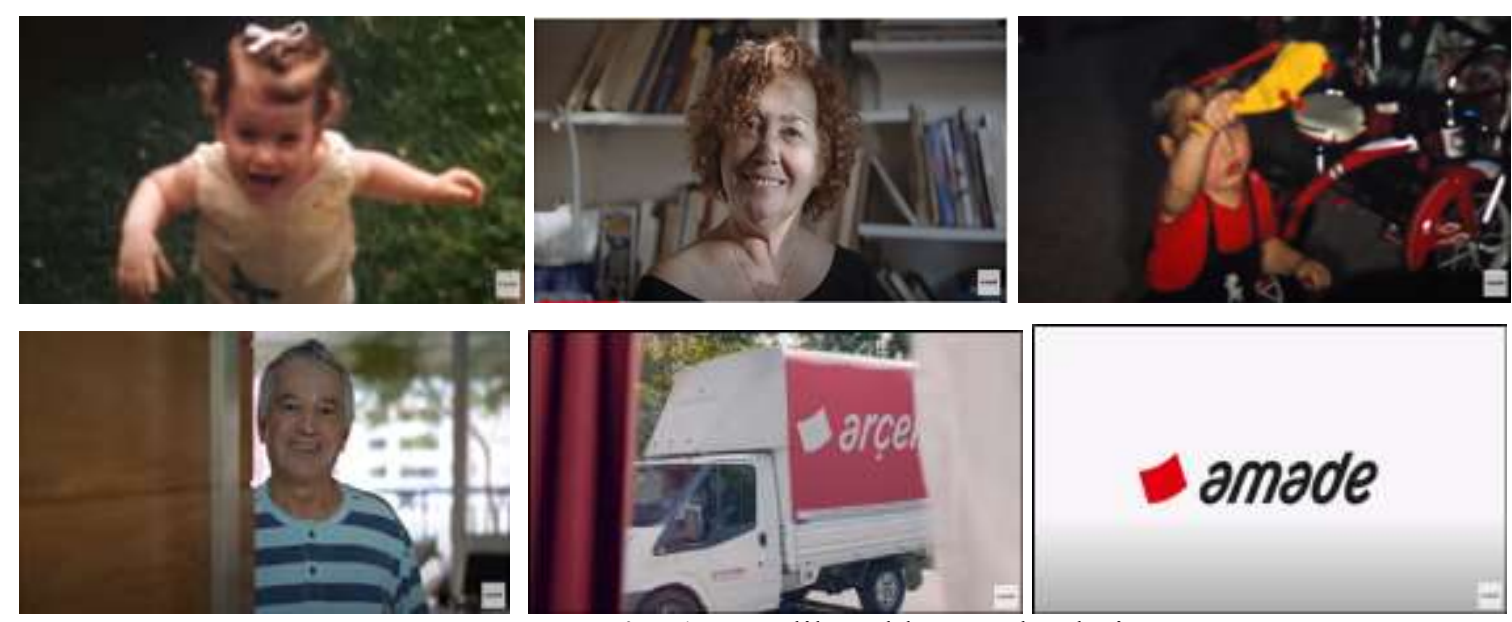

Resim 1: Arçelik Reklamı Sahneleri

Kaynak: https://www.youtube.com/watch?v=GsnGBYA7NuY

Reklamda duygusal bir fon müziği kullanılmıştır. Reklam, küçük bir kız çocuğun gülerek yürümesi ve hemen arkasından yaşlı bir kadının kameraya bakarak gülümsemesiyle başlamaktadır. Bu görüntülerin üzerine diş ses tarafindan "Annen hep derdi sana aman anneciğim dikkat et kendine, şimdi sen söylüyorsun annene, aman anneciğim dikkat et kendine." ifadesi söylenmektedir. Dilsel anlatımdan küçük kız çocuğun büyüdüğü ve küçükken onun için endişelenen annesi için artık onun endişelendiği anlaşılmaktadır. Daha sonraki karelerde ise elinde uçak uçuran küçük bir erkek çocuğu ve gülümseyerek kapıyı açan yaşlı bir adam gösterilmektedir. Söz konusu karelerde "Baban hep sorardl sana babacım gelirken ne getireyim, şimdi sen soruyorsun babana babacım gelirken ne getireyim." ifadesi dış ses tarafından seslendirilmektedir. Küçükken babası tarafından istekleri karşılanan erkek çocuk büyümüş ve artık babasının isteklerini karşılamaya çalışmaktadır. Reklamda genel olarak, yaşanan salgın nedeni ile daha fazla risk altında olan 65 yaş üstü için duyulan endişeler anlatılmaya çalışılmıştır. Görsel göstergelerle birlikte dilsel göstergelerin kullanılması yan anlamın kuvvetlenmesini sağlamaktadır. Barthes'a (2016) göre, görsel göstergeler tek başına bir anlam 
oluşturamamakta, dile ihtiyaç duymaktadır. Reklam filmi, Arçelik yazılı yeleklerini giymiş, Arçelik çalışanlarının yürüdüğü ve ardından Arçelik araçlarının Arçelik ürünleriyle yola çıktığı görüntüler ile devam etmektedir. Bu görüntüler üzerine dış ses şunları söylemektedir: "Biz de büyüklerimizin emrine amadeyiz. Bundan böyle Arçelik servis ve montaj önceliğini 65 yaş üstü büyüklerimize veriyor gelirken de isteyen büyüklerimizin market alışverişlerini yapıyoruz. Önce büyükler." Büyüklere verdiği öneme dikkat çeken marka, hizmet önceliğini 65 yaş üstüne vereceğini ifade etmektedir. Talep edilmesi durumunda büyüklerin market alışverişinin de Arçelik çalışanları tarafından yapılacağı dilsel olarak ifade edilmiştir. Türk toplumunun büyüklere saygı, yardımlaşma, dayanışma gibi toplumsal değerlerini markayla özdeşleştiren reklam filmi, markanın logosunun değişerek, hazır anlamına gelen 'amade' kelimesinin ekrana gelmesi ile sona ermektedir.

\section{Turkcell Reklamı}

Turkcell'in salgın dönemine yönelik hazırlamış olduğu reklam filminde Tarkan'ın “İnci Tanem” şarkısından bir bölümün yorumlandığı duygusal bir fon müziği kullanılmıştır.
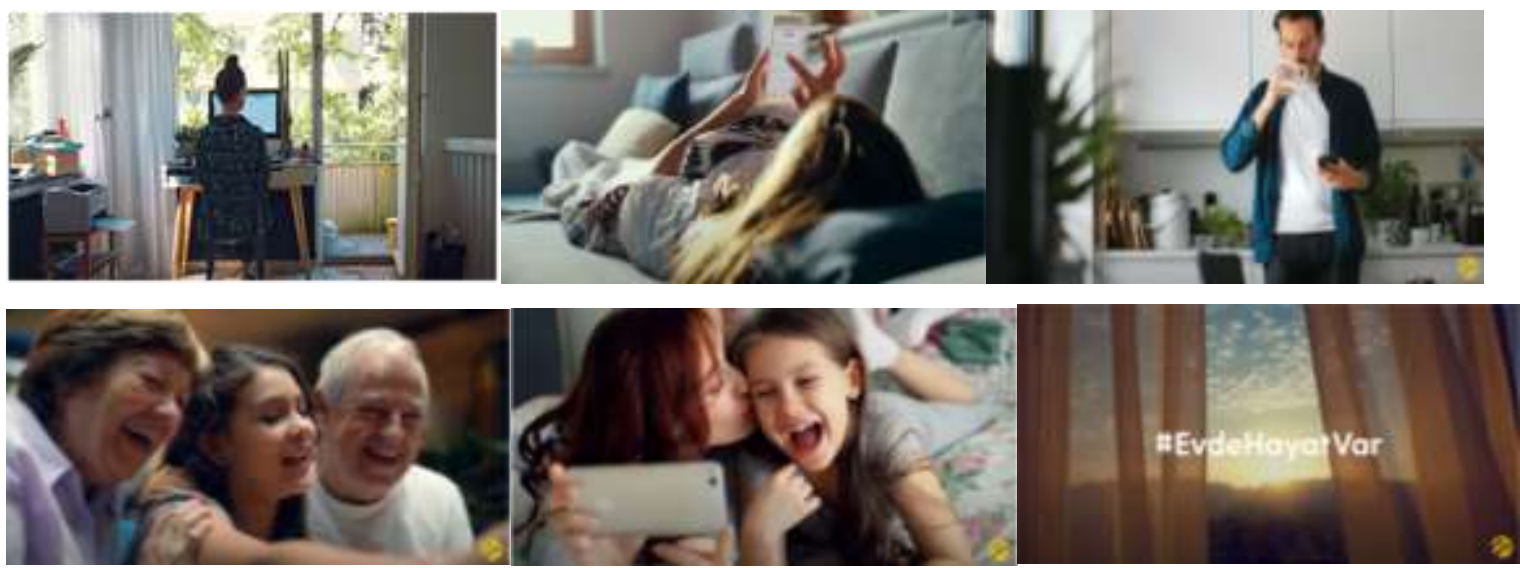

Resim 2: Turkcell Reklamı Sahneleri

Kaynak: https://www.youtube.com/watch?v=8PgwWc7nHTk

Özellikle evde kalmak zorunda olan risk grubundaki yaşlılar ve taşıyıcı olabilecek gençlerin görüntülerinin yansıdığı reklamda, "Evde hayat var" sloganı ile insanların salgın dönemini evde geçirmeleri için evde kalmaları yönünde çağrı yapılmaktadır. Reklamın ilk sahnelerinde evde yalnız olan gençlerin bilgisayar veya telefonları ile evden eğitim ve iş hayatına devam ettikleri göstereni ile Turkcell'in altyapısının, eğitim ve iş hayatını kesintisiz devam ettirecek teknolojiye sahip olduğu gösterilmektedir. Büyük ölçüde teknolojiye dayanan mevcut trend ile pandemi döneminde, insanların evden çalı̧̧abilmesi, uzaktan eğitim alabilmesi, çevrimiçi bankacılık işlemlerini yapabilmesi ve çevrimiçi mal /hizmet sipariş edebilmesi ile kişiden kişiye temas kolayca azalabilecektir (Wen vd., 2020). Sevdikleriyle telefonla iletişim kuran ailelerin gösterildiği sahnelerde de benzer şekilde Turkcell'in etkin bir dağıtım ağının olduğu ve Turkcell'in bu zor günlerde güçlü aile bağları olan Türk toplumunun sevdikleri ile iletişim ağının kopmaması için çalışmaya devam ettiği gösterilmektedir. Dış sesin "Sizin bağınız hiç kopmasin diye tüm enerjimizle çalışmaya devam ediyoruz." ifadesi ile de bu düşünce desteklenmektedir. Reklam, dış sesin, "Sabret Türkiye! Bir süre sevdiklerimizden, güzel ülkemizin sokaklarından, caddelerinden ayrı kalacağız. Ama merak etme, geçici bu ayrllık. \#EvdeHayatVar diyoruz ve sizin bağını hiç kopmasın diye tüm enerjimizle çalı̧̧maya devam ediyoruz." ifadesi ile sona ermektedir.

\section{Türkiye İş Bankası Reklamı Analizi}

2020 Mart ayında YouTube'da salgın dönemine yönelik en çok izlenen reklamlar içerisinde Türkiye İş Bankası'nın “El ele veremesek de 'el birliğiyle' hepsi geçecek.” sloganı ile yayınlanan reklamı yer almaktadır. 

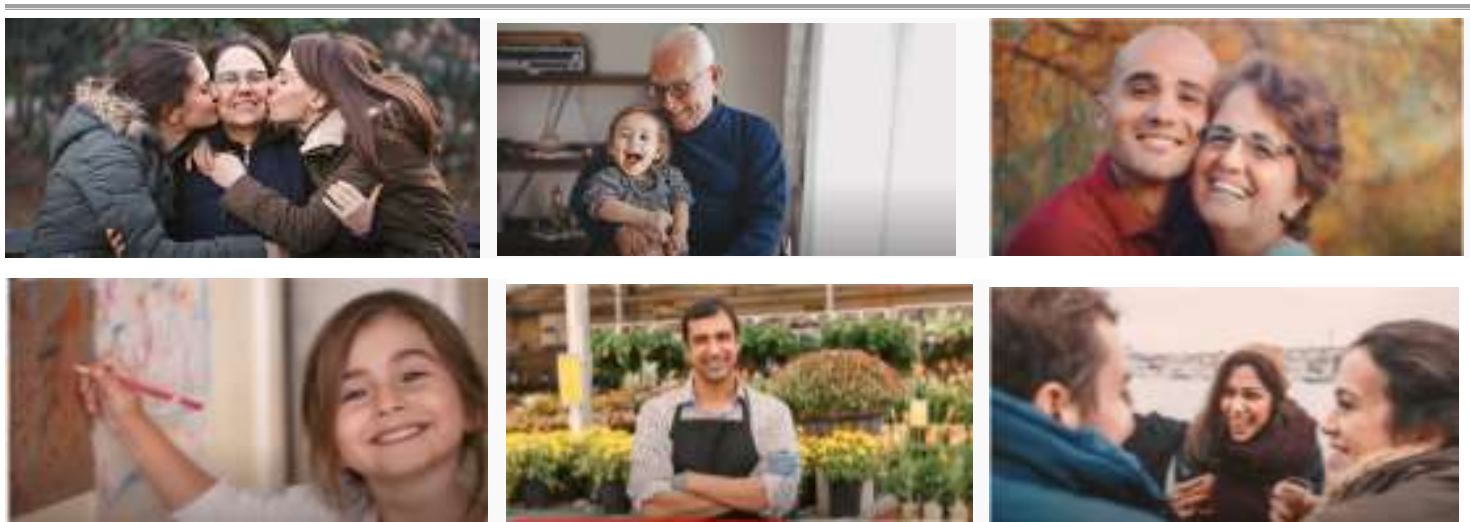

Resim 3: Türkiye İş Bankası Reklam Sahneleri

Kaynak: https://www.youtube.com/watch?v=IF7PzylVYpo

Cem Karaca'nın 'Bu son olsun' parçasının fon müziği olarak kullanıldığı reklam filminde fiziksel olarak el ele verilemese de bu zorlu dönemlerin beraber aşılacă̆ 1 mesajı verilmektedir. Türkiye İş Bankası reklamında, "Türk toplumunun sevdiklerine olan bağlılı̆̆ı" gösterileni; "dedenin torununa şefkatle bakması", "anne ve oğlunun sarılması", "annenin bebeğini koklaması" gibi gösterenlerle çağrıştırılmaktadır. Reklamda Türk toplumunun, sevdiklerinin yanında mutlu olduğu yan anlamı, görsellerin yer aldığı sahnelerde dış ses tarafından seslendirilen "Biz bizsiz yapamayız, sarılarak çoğalırız, koklayarak severiz." dilsel gösterge ile de desteklenmektedir. Reklamda "resim çizerken gülümseyen kız çocuğu", "gülümseyen çiçekçi”, "dışarıda çay içerken gülümseyen insanlar" gösterenleri ile de mutlu günlerin yakında tekrar geleceği gösterilmeye çalışılmaktadır. Dış ses tarafindan ifade edilen "Bugün biriktirdiğimiz umutlar, bir bakmışsınız bize hayat olur. El ele veremesek de "el birliğiyle" hepsi geçecek." sözleriyle de gösterilen desteklenmektedir. Türkiye İş Bankası'na yönelik herhangi bir vurgunun yapılmadı̆̆ reklam filminin sadece en son sahnesinde Türkiye İş Bankası'nın ismi ve "Türkiye'nin Bankası" sloganı yer almaktadır.

\section{Vakıfbank Reklamı}

Vakıfbank'ın salgın dönemine yönelik hazırladığı reklam filmi, "Korkma demiş marşımız, sen de sakın korkma." sözleriyle başlamakta ve geleceğe dair umut dolu sözler içermektedir.
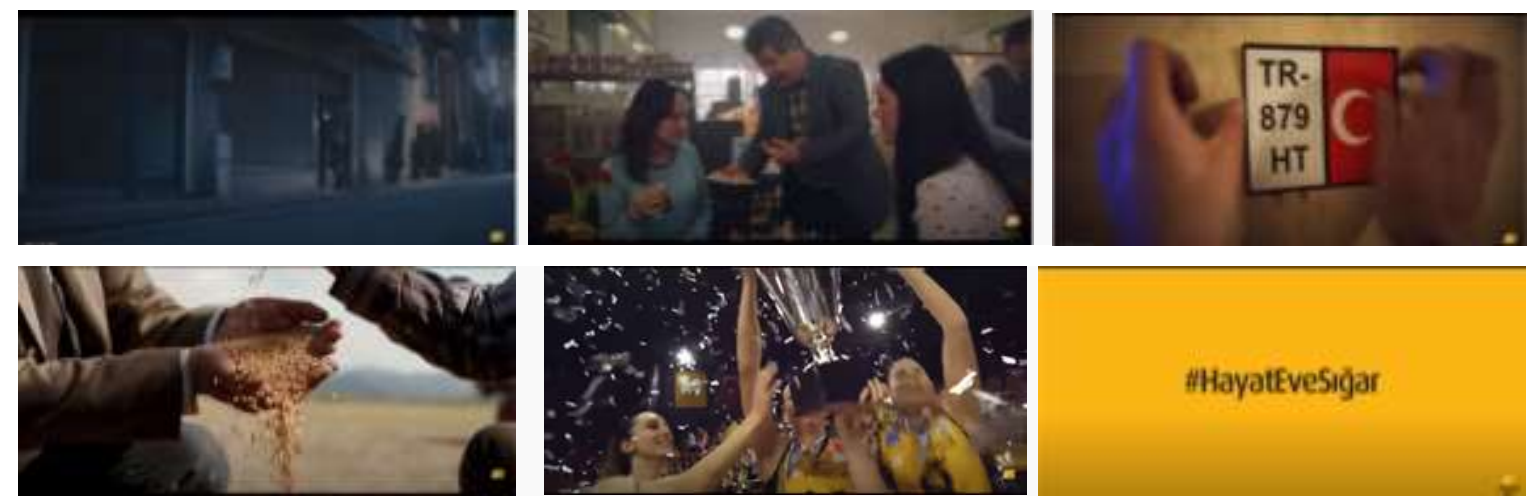

Resim 4: Vakıfbank Reklamı Sahneleri

Kaynak: https://www.youtube.com/watch?v=v3lVHoabpQs

Türkiye olarak zorlukların birlikte aşılacağının vurgulandığı reklam filminde "dükkanının kepengini kaldıran esnaf", "müşterilerine ikramda bulunan esnaf", "yurtdışına göndermek için hazırlanan ürün paketleri", "tarladan toplanan mahsuller" gösterenleri ile bu zor günlerin aşılacağı ve tekrar üretimin ve ticaretin başlayacağı gösterilmektedir. "Türkiye’yiz biz. Dün olduğu gibi bugün 
de, yarın da zorluklara boyun eğmeyiz. 83 milyon bir arada olur, bu zor günleri de birlikte aşarı, daha önce biz neleri aşmadık ki... Kavuşacağımız günler yakında, unutma." dilsel ifadeleri ile de gösterilen desteklenmektedir. Toplumun farklı kesimlerinden insanların yer aldığı reklam filminde, Vakıfbank'ın KOBI'nin, esnafin, çiftçinin, gençlerin, girişimcinin yani toplumun tüm kesiminin yanında olduğunu gösterilmekte ve banka "Türkiye'nin Yanındaki Güç” olarak kendisini konumlandırmaktadır.

\section{Beko Reklamı}

Beyaz eşya markası Beko'nun pandemi döneminde hazırlamış olduğu reklam filmi ise sağlık çalışanlarını ön plana çıkarmaktadır.
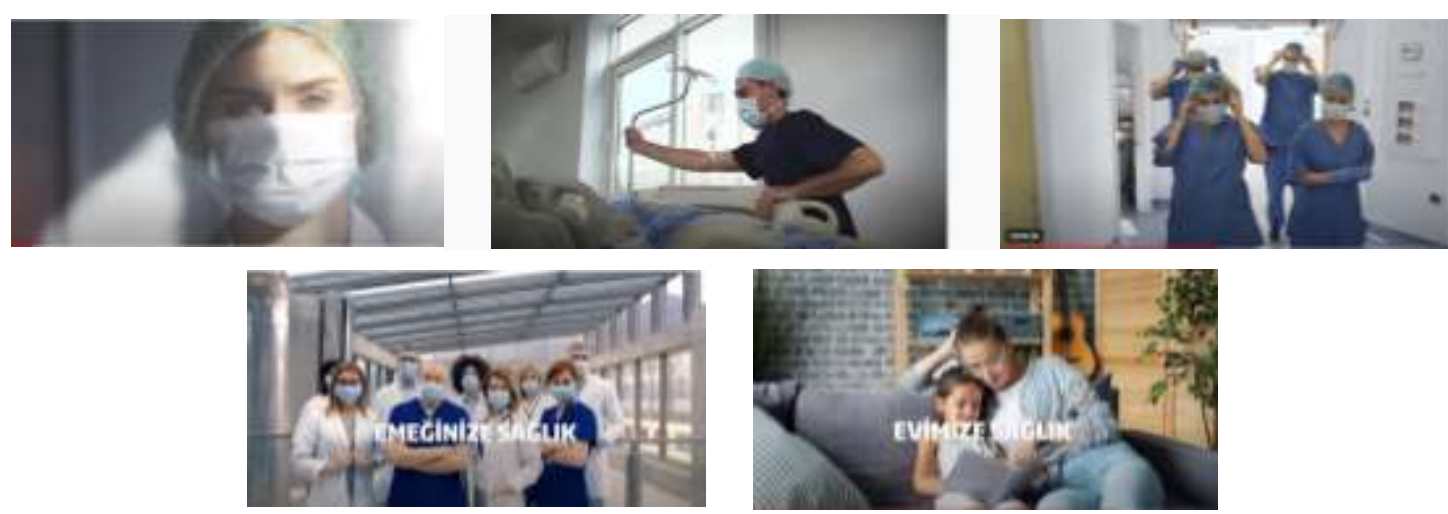

Resim 5: Beko Reklamı Sahneleri

Kaynak: https://www.youtube.com/watch?v=JNChaH4AGxs

Reklam filmi bir sağlık çalışanının yüzüne maske takmasıyla başlamakta ve reklam boyunca sağlık çalışanlarının hastalara müdahale için özveriyle koşuşturmaları gösterilmektedir. Dış ses tarafından sorulan "Onların kahramanlıkları bugüne özel değil. Bizim için hayatlarını ortaya koyan, canla başla savaşan sağlık çalışanlarına biz nasıl teşekkür ederiz?" sorusu ile de sağlık çalışanlarına duyulan minnettarlık ifade edilmektedir. Daha sonra dış sesin söylediği "Sağlık çalışanlarımız için hastanelere Beko ürünlerimizle destek oluyoruz." ifadesi ile Beko markasının hastanelere sağlık çalışanlarının bu zor dönemde kullanması için ürünleri ile destek olduğu gösterilmektedir. Reklamda bir taraftan sağlık çalışanları birer kahraman olarak gösterilirken bir taraftan da Beko markasının sağlık sektörüne vermiş olduğu destek vurgulanmaktadır. He ve Harris (2020)'e göre tüketiciler, kriz sırasında çalışanlarına yardım eden, para ve ekipman bağışlayan markalarıyla gurur duyacaklardır. Reklamın sonunda sağlık çalışanlarının yer aldığı sahnede "emeğinize sağlık" sloganı, evden görüntülerin yer aldığı sahnede ise "evimize sağlık" sloganı yer almıştır.

\section{Yemek Sepeti Reklamı}

Yemek Sepeti, pandemi döneminde hazırladığı reklam filminde, salgın günlerinde de ara vermeden çalışmaya devam eden restoran çalışanlarının emeklerine dikkat çekmektedir. 

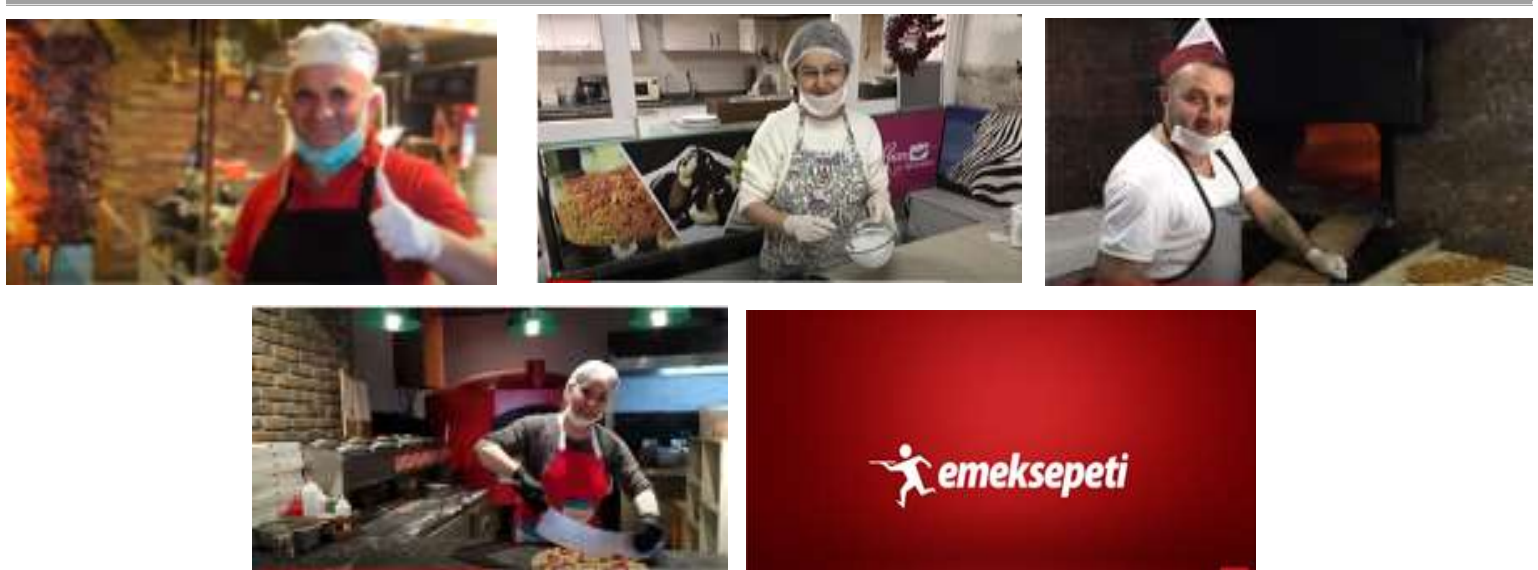

Resim 6: Yemek Sepeti Reklamı Sahneleri

Kaynak: https://www.youtube.com/watch?v=gcPBnK7PRS4

Yemek Sepeti reklamında yer alan sahnelerde, "üye restoranların çalışanlarının maske, bone ve eldiven ile yemekleri hazırladığı" göstereni ile "Yemek Sepeti'ne üye restoranlar salgın döneminde temizlik ve hijyen kurallarına uyarlar" düşüncesi iletilmeye çalışılmaktadır. Reklam filminde "döner, mantı, lahmacun, pizza, hamburger, kebap gibi her damak zevkine uygun çeşitli yemek görselleri" göstereni ile Yemek Sepeti'nin restoran ağının ne kadar geniş olduğu gösterilmektedir. Bu düşünce reklamdaki "Osman Abi'nin döneri, Çiğdem Abla'nın mantısı, Ali Usta'nın pidesi ve daha binlercesi" ifadeleri ile desteklenmektedir. Dolayısılla reklamda dilsel göstergelerle, görsel göstergelerin aktarmak istediği anlam da desteklenmiştir. Reklam farklı restoranlarda çalışan kişilerin yemek hazırlarken çekilen fotoğraflarının yer aldığı sahneler ile devam etmekte ve diş sesin "Biz hep yemeklerini konuştuk şimdi de gelin emeklerini konuşalım. Onlar restoranları ziyarete kapalı olsa da bu zor zamanlarda ayakta kalmak için mutfaklarını paket servise açmaya devam ediyor, onların alın teri ve emeği biz evde kalalım diye hepsinin emeklerine sağlık, dişarda tekrar buluşana kadar burası artık emek sepeti." ifadesi ile son bulmaktadır. Restoran çalışanlarının yemek hazırlama sahnelerinin gösterenleri ile salgın döneminde de paket servislerin devam edeceği gösterilmektedir. Reklamda, zor zamanlarda yardımlaşma bilinciyle hareket eden Türk toplumunun, pandemi döneminde de sipariş vererek restoran çalışanlarının bu süreçte maddi açıdan zor durumda kalmalarının önüne geçebileceği gösterilmektedir. Restoranların sipariş sisteminin devam ettiği vurgulanmakta, Yemek Sepeti logosunun "emeksepeti" olarak değiştirilmesiyle çalışanların emeklerine teşekkür edilmekte ve "Dışarıda tekrar buluşana kadar burası artık emek sepeti." sözleri ile de bu yan anlam desteklenmektedir.

\section{QNB Finansbank Reklamı}

Son olarak ele alınan reklam filmi ise QNB Finansbank'ın pandemi döneminde hazırlamış olduğu reklam filmidir.
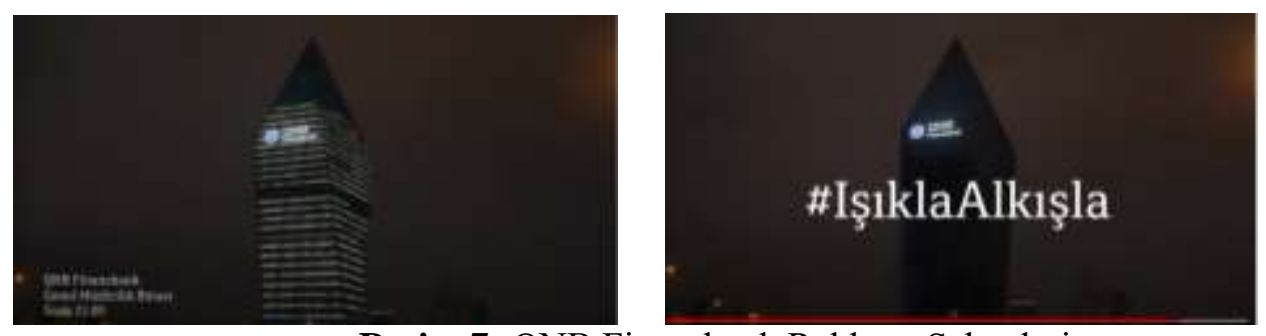

Resim 7: QNB Finansbank Reklamı Sahneleri

Kaynak: https://www.youtube.com/watch?v=ialr6CLyzRY 
Reklam filmi QNB Finansbank Genel Müdürlük binasının gösterilmesi ile başlamakta ve reklam boyunca ekranda aynı görüntü yer almaktadır. Ekranda saatin 21.00 olduğu belirtilmekte ve reklam boyunca binanın tüm 1şıkları yakılıp söndürülmektedir. Dış ses bu sırada "Bu yanıp sönen ışıllar, özveriyle görevlerini sürdüren sağllk, market, belediye çalışanlarına, başta gıda ve ilaç sanayinde olmak üzere üretimi devam ettiren işçilere, eczacılara, kuryelere, basın mensuplarına, polislere, askerlere, bankacılara ve QNB Finansbank çalışanlarına... Türkiye evde kalsın diye canla başla çalışan herkese minnetimizin işareti." ifadesini seslendirmektedir. Banka başta Covid-19 salgınıla mücadelede en büyük risk grubunda yer alan sağlık çalışanları olmak üzere bu süreçte dışarıda çalışmaya devam etmek zorunda olan diğer meslek gruplarına minnettarlığını göstermek için güzel günler gelene kadar her akşam aynı saatte 1şık yakıp söndürmeye devam edeceğini belirtmektedir.

Araştırma kapsamında incelenen reklam filmlerinin göstergebilimsel çözümlemeleri sonucu elde edilen birlik ve beraberlik, yardımlaşma, dayanışma, minnettarlık gibi ortak temalara ilişkin genel değerlendirme tablosu aşağıda gösterilmiştir.

Tablo 1: KSS Kapsamında Değerlendirilen Reklamlar

\begin{tabular}{|c|c|c|}
\hline Reklam & Gösteren & Gösterilen \\
\hline Arçelik & $\begin{array}{l}\text { Küçük çocuklar, yaşlılar, } 65 \text { yaş üstüne } \\
\text { hizmet sunan Arçelik çalışanları }\end{array}$ & $\begin{array}{l}\text { Türk toplumunun büyüklere olan saygısı ve } \\
\text { yardımlaşma bilinci pandemi döneminde de } \\
\text { devam etmektedir. }\end{array}$ \\
\hline Turkcell & Ev ortamında zaman geçiren gençler, aileler & $\begin{array}{l}\text { Toplumsal birlik ve beraberliğe önem veren } \\
\text { Türk toplumu, pandemi döneminde evde } \\
\text { kalmak zorunda olsa bile sevdikleriyle } \\
\text { iletişim kurmaya devam etmekte, bağlarını } \\
\text { koparmamaktadır }\end{array}$ \\
\hline $\begin{array}{l}\text { Türkiye İş } \\
\text { Bankası }\end{array}$ & $\begin{array}{l}\text { Gülümseyerek sarılan insanlar, gülümseyen } \\
\text { esnaf, çay içen mutlu insanlar }\end{array}$ & $\begin{array}{l}\text { Toplumsal birlik ve beraberlik sayesinde, } \\
\text { salgın sona erdiğinde iş yerleri tekrar } \\
\text { açılacak, insanlar bir araya geldikleri eski } \\
\text { mutlu günlerine geri döneceklerdir. }\end{array}$ \\
\hline Vakıfbank & $\begin{array}{l}\text { Dükkanının kepengini kaldıran esnaf, } \\
\text { müşterilerine hizmet sunan esnaf, ihracat } \\
\text { için hazırlanan paketler, tarladan toplanan } \\
\text { mahsuller }\end{array}$ & $\begin{array}{l}\text { Bu zor günlerin birlik ve beraberlik } \\
\text { sayesinde geçeceği, esnafin, çiftçinin, } \\
\text { KOBİ'nin yeniden çalışmaya başlayarak } \\
\text { tekrar yüzünün güleceği }\end{array}$ \\
\hline Beko & Maskeleri ile koşuşturan sağlık çalışanları & $\begin{array}{l}\text { Sağlık çalışanlarının salgın dönemindeki } \\
\text { kahramanlıklarına duyulan minnettarlık. }\end{array}$ \\
\hline Yemek Sepeti & $\begin{array}{l}\text { Restoranlar kapalı olsa da paket servis için } \\
\text { hizmet devam eden restoran çalışanları }\end{array}$ & $\begin{array}{l}\text { Zor günlerde dayanışma içerisinde olan } \\
\text { Türk toplumunun, Yemek Sepeti'nden } \\
\text { sipariş vererek salgın döneminde zor } \\
\text { durumda kalan restoran sahiplerine destek } \\
\text { verebileceği }\end{array}$ \\
\hline $\begin{array}{l}\text { QNB } \\
\text { Finansbank }\end{array}$ & $\begin{array}{l}\text { Saat } 21.00 \text { 'da bütün 1şıkları yakıp } \\
\text { söndürülen QNB Finansbank Genel } \\
\text { Müdürlük binası }\end{array}$ & $\begin{array}{l}\text { Başta sağlık çalışanları olmak üzere bu zor } \\
\text { dönemde çalışmak zorunda olanlara duyulan } \\
\text { minnettarlık }\end{array}$ \\
\hline
\end{tabular}




\section{Sonuç}

Dünya çapında büyük bir kaosa yol açan Covid-19 salgını, başta ulaşım ve turizm sektörü olmak üzere pek çok sektördeki markayı derinden etkilemiştir. Bu süreçte reklam vermeye devam eden markaların reklam stratejileri de yaşanan sağlık krizinden etkilenmiştir. Pandemi sürecinde KSS bilinciyle hareket eden markalar reklamlarında, insanların toplumsal kaygılarını dikkate alan duygusal çekicilik içeren mesajlara odaklanmaya başlamışlardır. Çalışma kapsamında, 2020 Mart ayında YouTube'da en çok izlenen ve Covid-19 salgınını konu edinen yedi reklam filmi göstergebilimsel analiz yöntemi ile ele alınmıştır. İncelenen yedi reklam filminin de ortak noktası birlik ve beraberlik ile bu krizin aşılacağıdır. Arçelik markasına ait incelen reklam filmi, 65 yaş üstü kişilere odaklanmakta ve Türk toplumunun büyüklerine verdiği değeri içeren sözel ve görsel kodlar içermektedir. Turkcell ve Türkiye İş Bankası reklamlarında, bireyler evin içerisinde gösterilerek sosyal izolasyonun önemine dikkat çekilmektedir. Türk toplumunun aile kurumuna ilişkin değerlerinin sözel ve görsel kodlarla iletilmeye çalışıldığı bu reklamlarda, zor günlerin birlik ve beraberlik duygusu ile aşılacağı anlatılmaktadır. Vakıfbank'a ait reklamda da benzer şekilde toplumsal dayanışma ile her türlü zorluğun aşılacağı vurgulanmakta, Vakıfbank'ın toplumun her kesiminin yanında olduğu görsel ve sözel kodlarla vurgulanmaktadır. Yemek Sepeti reklamı ise zor günlerde dayanışma içerisinde olan Türk toplumunun, pandemi döneminde de zor durumda kalan restoranlardan yemek sipariş vererek onlara destek olabileceğine dikkat çekmektedir. Sağlik çalışanlarını ön plana çıkaran Beko ve QNB Finansbank markaları ise reklamlarında minnettarlık, dayanışma gibi gösterge kodlarına daha çok yer vermiştir. Reklamlar genel olarak değerlendirildiğinde, insanların evde kalmalarına odaklanan ve salgınla ilgili endişelerini azaltmaya çalışan benzer mesajlar verdikleri görülmektedir. Duygusal fon müziklerinin kullanıldığ reklamlarda, umut içeren söylemlerle insanlarda oluşan karamsar duygular bertaraf edilmeye çalışılmıştır. Yedi reklam filminde de "ben" yerine "biz" olgusuna yer verilmiş ve toplumsal birlik ve beraberliğe vurgu yapan sözel ve görsel göstergeler belirgin biçimde yer almıştır. Markalar reklamlarında her ne kadar ürün tanıtımına yönelik vurgudan kaçınmış olsalar da, bu süreçte hizmetlerini aksatmadan devam ettirdikleri dilsel ve/veya görsel göstergelerle gösterilmiştir. İncelenen yedi reklam filminin YouTube'da 2020 Mart ayı içerisinde en çok izlenen on reklam filmi içerisinde yer alması, böyle zamanlarda toplumun markalardan sosyal sorumluluk bilinci ile hareket etmeleri konusunda beklentilerinin arttığını göstermektedir.

Pandemi dönemindeki pazarlama ve reklam stratejileri, pandeminin getirdiği zorluklarla yüzleşebilmek için yaratıcılığa ve yeniliğe dayanmalıdır. Markaların kriz dönemlerinde de içerik üretimini sürdürmeleri, hedef kitlesine uygun, topluma fayda sağlayacak şekilde iletişime devam etmesi son derece önem kazanmaktadır. Markaların pazarlama iletişimi yaklaşımında ürün ve fiyat odaklı bakış açısından ziyade ekonomik belirsizliklerin olduğu böyle dönemlerde topluma fayda odaklı bir bakış açısı kazanmaları daha doğru olacaktır. İçinde bulunduğumuz pandemi döneminde, markaların toplum sağlığını ne kadar önemsediğini gösteren KSS projelerini hayata geçirmeleri tüketicilerin markaya bakış açılarını etkileyecektir. Tüketiciler, Covid-19 dönemine baktıklarında markaların nasıl tepki verdiğini hatırlayacaklardır. Bu nedenle, markaların bu süreci doğru bir biçimde yönetmeleri ve tüketicilerin daha duyarlı hale geldiği böyle dönemlerde, KSS ile ilgili kabul gören çabalar içinde olmaları önem kazanmaktadır. İnsanların pandemi nedeni ile evde daha fazla vakit geçirmeleri, daha çok televizyon izlemeleri ve sosyal medyaya daha fazla vakit ayırmaları anlamına gelmektedir. Dolayısıyla bu dönemde yapılan reklamlar kısa bir süre içerisinde çok geniş kitlelere ulaşmaktadır. Özellikle bu dönemde yapılan reklamlarda, tüketiciyi ürünü satın almaya çağırmak yerine bu belirsiz zamanlarda onlar için orada olduklarını gösteren sosyal mesajlar veren markaların tüketicinin gözünde değerinin artması muhtemeldir.

Sonuç olarak bu çalışma ile Covid-19 salgınının reklamlar üzerindeki etkisi ortaya koyulmaya çalışılmıştır. Araştırma kapsamında değerlendirilen reklamlarda, birlik beraberlik, yardımlaşma, dayanışma gibi toplumu birleştiren ortak temaların kullanılması, KSS reklamcılı̆̆ının 
böyle dönemlerde önem kazandığını göstermektedir. Daha sonraki çalışmalarda, markaların pandemi dönemindeki reklamlarına yönelik tüketici tepkilerini ölçmek ve bu tarz reklamların tüketicilerin markalara olan tutumlarını, satın alma niyetlerini değiştirip değiştirmediğini ortaya koymak amacıyla kantitatif çalışmalar yapılabilir.

\section{Kaynakça}

Aktan, C.C., \& Börü, D. (2006). Kurumsal sosyal sorumluluk. Kurumsal sosyal sorumluluk işletmeler ve sosyal sorumluluk (Coşkun Can Aktan, Ed.). İGİAD Yayınları.

Alcaniz, E.B. , Caceres, R.C., \& Perez, R.C.(2010). Alliances between brands and social causes: The influence of company credibility on social responsibility image. Journal of Business Ethics, 96,169-186. DOI 10.1007/s10551-010-0461-x

Argüden, Y. (2002). Kurumsal Sosyal Sorumluluk. Rota Yayın Yapım.

Baker, W.E., \& Sinkula, J.M. (2005). Environmental marketing strategy and firm performance: effects on new product performance and market share. Journal of the Academy of Marketing Science, 33 (4), 461-75. DOI: 10.1177/0092070305276119

Barthes, R. (2016). Göstergebilimsel serüven (Mehmet Rifat, Sema Rifat, Çev. 8.Baskı). Yapı Kredi Yayınları.

BBC (2020a). Coronavirus: Twitter boss pledges $\$ 1 \mathrm{bn}$ for relief effort. https://www.bbc.com/news/technology-52209690 Erişim Tarihi: 25.08.2020

BBC (2020b). Coronavirus: Louis Vuitton owner to start making hand sanitiser. https://www.bbc.com/news/business-51868756 Erişim Tarihi:25.08.2020

BBC (2020c). Alibaba's Ma donates coronavirus test kits to US. https://www.bbc.com/news/business-51904379 Erişim Tarihi:25.08.2020

Berman, S., Wicks, A., Kotha, S., \& Jones, T. (1999) Does stakeholder orientation matter? The relationship between stakeholder management models and firm financial performance. Academy of Management Journal, 42(5), 488-506. http://dx.doi.org/10.2307/256972

Bortree, D.S., Ahern, L., Smith, A.N., \& Dou, X. (2013). Framing environmental responsibility: 30 years of CSR messages in national geographic magazine. Public Relations Review, 39(5), 491-496. https://doi.org/10.1016/j.pubrev.2013.07.003

Bowen, R.H. (1953). Social responsibility of the businessman. Harper and Row.

Carroll, A.B. (1999). Corporate social responsibility: evolution of a definitional construct. Business \& Society, 38(3), 268-295. https://doi.org/10.1177/000765039903800303

Carroll, A.B., (1991), The Pyramid of Corporate Social Responsibility: Toward the Moral Management of Organizational Stakeholders. Business Horizons, 34(4), 39-48. https://doi.org/10.1016/0007-6813(91)90005-G

Chahal, H., \& Sharma, R. (2006). Implications of corporate social responsibility on marketing performance: A conceptual framework. Journal of Services Research 6(1), 205-216. https://search.proquest.com/scholarly-journals/implications-corporate-social-responsibilityon/docview/195551747/se-2?accountid=16645

Clow, K. E., \& Baack, D. (2016). Bütünleşik reklam, tutundurma ve pazarlama iletişsimi (Gülay Öztürk, Çev. Ed.). Nobel Yayıncılık. 
Commission of the European Communities (2001). Green paper-promoting a European framework for corporate social responsibility https://ec.europa.eu/transparency/regdoc/rep/1/2001/EN/1-2001-366-EN-1-0.Pdf

Commission of the European Communities (2011). Corporate Social Responsibility: a new definition, a new agenda for action https://ec.europa.eu/commission/presscorner/detail/en/MEMO_11_730

Edelman (2020). Trust barometer special report: brand trust and coronavirus pandemic. https://www.edelman.com/research/covid-19-brand-trust-report Erișim Tarihi:10.09.2020

Elden, M. (2015). Reklam ve reklamcılık. Say Yayınları.

Elden, M., Ulukök, Ö., \& Yeygel, S. (2005). Şimdi Reklamlar. İletişim Yayınları.

Erkman Akerson, F. (2005). Göstergebilime giriş. Multilingual.

Farache, F., \& Perks, K.J. (2010). CSR advertisements: A legitimacy tool?. Corporate Communications: An International Journal, 15(3), 235-248. https://doi.org/10.1108/13563281011068104

He, H., \& Harris, L., (2020). The impact of Covid-19 pandemic on corporate cocial responsibility and marketing philosophy. Journal of Business Research, 116, 176-182. https://doi.org/10.1016/j.jbusres.2020.05.030

Kotler, P., \& Armstrong, G. (2018). Pazarlama ilkeleri (A.Ercan Gegez, Çev. Ed.). Beta Yayınları.

Kotler, P., \& Lee, N. (2006). Kurumsal sosyal sorumluluk (Sibel Kaçamak, Çev.). MediaCat Yayınları.

Küçükerdoğan, G. R. (2011). Reklam Nasıl Çözümlenir? Beta Yayınları.

Küçükerdoğan, G.R. (2005). Reklam Söylemi. Es Yayınları.

Lai, C.S., Chiu, C.J Yang, C.F., \& Pai, D.C. (2010), The effects of corporate social responsibility on brand performance: The mediating effect of industrial brand equity and corporate reputation. Journal of Business Ethics, 95(3), 457-469. DOI 10.1007/s10551-010-0433-1

Maignan, I., Ferrell, O. C., \& Ferrell, L. (2005). A stakeholder model for implementing social responsibility in marketing. European Journal of Marketing, 39(9/10), 956-977. DOI: $10.1108 / 03090560510610662$

Maignan, I. (2001). Consumers' perceptions of corporate social responsibilities: A cross-cultural comparison. Journal of Business Ethics, 30(1), 57-72. DOI: 10.1023/A:1006433928640

McWilliams,A.,\&Siegel, D. (2001). Corporate social responsibility: A theory of the firm perspective. Academy of Management Review, 26(1), 117-127. https://doi.org/10.2307/259398

Ogrizek, M. (2002). The effect of corporate social responsibility on the branding of financial services. Journal of Financial Services Marketing, 6(3), 215-228. https://doi.org/10.1057/palgrave.fsm.4770053

Salmones, M.G., \& Perez, A. (2017). Effectiveness of CSR advertising: The role of reputation, consumer attributions and emotions. Corporate Social Responsibility and Environmental Management, 25(2), 194-208. https://doi.org/10.1002/csr.1453

Sayın, Ö. (2014). Göstergebilim ve sosyoloji. Anı Yayıncılık.

Shaikh, A., (2020). Effective factors in changing the buying behavior of consumer due to Covid-19, Studies in Indian Place Names, 40 (68), 408-414. 
Covid-19 Pandemisi Dönemindeki Reklamların Kurumsal Sosyal Sorumluluk Açısından... 3791

Smith, P.L., \& An, H. (2019), Are corporate social responsibility and advertising complements or substitutes in producing firm reputation? Applied Economics, 51(21), 2275-2288. https://doi.org/10.1080/00036846.2018.1540858

Tanrıöğen, A. (2009). Bilimsel araştırma yöntemleri. Seçkin Yayıncılık.

Wen, J., Kozak, \& M., Yang, S., \& Liu, F., (2020), COVID-19: Potential effects on chinese citizens' lifestyle and travel. Tourism Review, https://doi.org/10.1108/TR-03-2020-0110

Yang, C.-M. (2018). Effects of message strategy and need for cognition (NFC) on consumer attitudes: A case of corporate social responsibility (CSR) advertising. Open Journal of Business and Management, 6(3), 714-732. https://doi.org/10.4236/ojbm.2018.63055

Yıldırım, A., Şimşek, H.(2008). Sosyal bilimlerde nitel araştırma yöntemleri (6. Baskı). Seçkin Yayınc1lik.

YouTube Ads Leaderboard-Mart 2020. https://www.thinkwithgoogle.com/intl/tr-tr/pazarlamastratejileri/video/youtube-ads-leaderboard-mart-2020/ 